\title{
Kualitas Visual Fasade Bangunan Modern Pasca Kolonial di Jalan Kayutangan Malang
}

\author{
Nur Fauziah ${ }^{1}$, Antariksa ${ }^{2}$, Jenny Ernawati ${ }^{3}$ \\ Program Magister Arsitektur Lingkungan Binaan \\ Fakultas Teknik Universitas Brawijaya \\ nunungweasley@yahoo.com
}

\begin{abstract}
ABSTRAK
Kota Malang adalah salah satu kota hasil rancangan kolonial Belanda yang dirancang dengan memperhatikan estetika lingkungan perkotaan. Koridor Jalan Kayutangan merupakan koridor jalan bersejarah yang memegang peranan penting terhadap perkembangan fisik Kota Malang. Pada konteks visual arsitektural, deretan fasade bangunan di sepanjang Jalan Kayutangan merupakan elemen utama pembentuk keindahan visual dan karakter khas di koridor Kayutangan. Tujuan penelitian ini adalah untuk mengetahui penilaian masyarakat umum dan professional di bidang arsitektur tentang peranan elemen visual terhadap tampilan fasade bangunan modern pasca kolonial, serta untuk mengidentifikasi elemen visual yang paling berpengaruh terhadap tampilan fasade bangunan modern pasca kolonial di koridor Kayutangan. Metode yang digunakan adalah metode kuantitatif dengan metode analisis independent sample t-test, analisis faktor, dan analisis regresi linier berganda. Hasil penelitian menunjukkan bahwa penilaian antar kedua kelompok responden tidak jauh berbeda dan berada pada rentang skala penilaian "agak penting" dan "penting". Elemen visual yang paling berpengaruh pada fasade bangunan modern pasca kolonial di Jalan Kayutangan yaitu Komponen Geometri (gaya arsitektural, bentuk fasade, garis horisontal, dan garis vertikal) dan Komponen Efek Raba Visual \& Dimensi Warna (tekstur, ornamen, material, warna muka bangunan, kemurnian warna, serta kecerahan warna).
\end{abstract}

Kata kunci: unsur visual, fasade bangunan modern, Jalan Kayutangan

\begin{abstract}
Malang is one of the cities designed by Dutch with spesific attention to the aesthetic of urban environments. Kayutangan Street is a historic street corridor which plays a prominent role on the physical development of the city of Malang. In visual architectural context, a row of building facades along the Kayutangan streetscape is the main element of visual beauty and character creation of the characteristic in the Kayutangan corridor. The aims of this research are to investigate the general public and professional in the field of architecture judgment about the role of visual elements to the appearance of modern building facades in Kayutangan corridor, as well as to find out the most influential visual element to the appearance of modern building facades at Kayutangan Street. The method used is quantitative method by the independent sample t-test, factor analysis, and multiple linear regression analysis. The results showed that both groups of respondents rating are not much different, on a range of "less important" to "important" assessment scale. The visual components which are the
\end{abstract}


most influential on modern building facades in Kayutangan Street are Geometric Component (architectural style, facade form, horizontal line, and vertical line). The next influential component is Visual Touching Effect \& Color Dimension Component (texture, decorative ornament, material, facade color, saturation, brightness)

Keywords: visual elements, modern building facade, Kayutangan streetscape

\section{Pendahuluan}

Persepsi visual masyarakat terhadap kota secara keseluruhan, baik bentuk dan struktur tata kotanya, massa-massa bangunan, maupun elemen-elemen lansekapnya, akan menentukan karakter kota tersebut, yang tentunya persepsi visual masyarakat sangat erat kaitannya dengan aspek politik, ekonomi, sosial, budaya, serta sejarah perjalanan kota tersebut.

Kota Malang merupakan kota bentukan kolonial Belanda yang terencana dengan baik pada awal pembentukannya. Seiring pembangunan dan perkembangan kota, terjadi banyak perubahan dan pergeseran dari wujud fisik kota, sehingga karateristik kota pun mulai terkikis. Secara visual arsitektural, perubahan yang paling mudah diamati adalah berupa perubahan fasade bangunan di sepanjang jalan utama kota.

Jalan Kayutangan adalah salah satu jalan yang memegang peranan penting bagi perkembangan Kota Malang. Jalan ini merupakan sumbu utama arah utaraselatan yang sejak awal pembangunannya telah memegang peranan penting sebagai kawasan pusat perdagangan dan jalur lalu lintas utama yang menghubungkan Malang dengan luar kota. Koridor Jalan Kayutangan merupakan salah satu koridor jalan bersejarah yang membentuk karakter khas Kota Malang, yang secara visual dibentuk oleh deretan fasade bangunan di sepanjang Jalan Kayutangan.

Koridor ini seharusnya tetap terjaga karakteristiknya, sehingga pembangunan dan pelestarian di sepanjang jalan ini harus mengacu pada suatu kebijakan dan guidance yang ketat dan detail. Deretan fasade bangunan tersebut seyogyanya dapat senantiasa menciptakan estetika lingkungan perkotaan, serta memberikan kenyamanan visual bagi masyarakat penghuni Kota Malang. Oleh karenanya, maka sangat penting untuk mengetahui unsur visual yang paling berpengaruh terhadap pembentukan kualitas visual fasade bangunan modern pasca kolonial di Jalan Kayutangan. Unsur visual pembentuk fasade terdiri dari gaya arsitektural (Portella, 2007; Askari, 2009), bentuk fasade (Ittelson, 1960 dalam Rapoport, 1977; Smardon, 1986; Portella, 2007; dan Askari, 2009), garis (Smardon, 1986; dan Masri, 2010) yang terdiri dari unsur garis horisontal dan garis vertikal, bidang (Portella, 2007; Masri, 2010) yang terdiri dari elemen pintu (perulangan bentuk pintu, bentuk pintu dan proporsi pintu) dan elemen jendela (perulangan bentuk jendela, bentuk jendela dan proporsi jendela), warna (Ittelson, 1960; Smardon, 1986; Portella, 2007, Askari, 2009; dan Masri, 2010) yang terdiri atas jenis warna, kemurnian warna dan kecerahan warna, tekstur (Ittelson, 1960; Smardon, 1986; Portella, 2007; Askari, 2009; dan Masri, 2010), ornamen dekoratif 
(Portella, 2007; Askari, 2009), dan material (Askari, 2009; Masri, 2010). Penelitian ini bertujuan untuk menggali penilaian masyarakat dan profesional mengenai peranan masing-masing unsur visual terhadap tampilan fasade bangunan modern pasca kolonial di Jalan Kayutangan, serta untuk mengetahui elemen visual yang paling berpengaruh terhadap tampilan visual fasade bangunan modern pasca kolonial di Jalan Kayutangan.

\section{Bahan dan Metode}

Penelitian ini menggunakan metode kuantitatif dengan penyebaran kuesioner untuk menggali penilaian masyarakat dan profesional tentang peranan masingmasing unsur visual terhadap tampilan fasade bangunan modern di Kayutangan. Teknik sampling menggunakan non-probability sampling, yaitu purposive judgement sampling. Pada penelitian ini, populasinya adalah masyarakat Kota Malang. Adapun proses pemilihan sampel dari keseluruhan populasi, yaitu sebagai berikut:

- Masyarakat Kota Malang yang berada dan beraktifitas di sepanjang koridor Jalan Kayutangan pada waktu penyebaran kuisioner dilaksanakan. Adapun kriteria responden pada kelompok masyarakat umum ini adalah masyarakat yang berusia minimal 17 tahun dan sehat jasmani dan rohani, sehingga dapat memberikan penilaian dengan baik. Kelompok ini terdiri dari 90 orang sampel. Pertimbangan pemilihan sampel ini yaitu bahwa masyarakat yang berada di lokasi studi pada waktu penyebaran kuesioner, dianggap lebih mampu menilai stimuli dengan baik karena mereka berada di lokasi studi. Dengan demikian, maka penilaian yang diberikan diharapkan dapat lebih representatif dibandingkan dengan masyarakat yang berada di lokasi lain di luar wilayah studi.

- Masyarakat dari kalangan profesional di bidang arsitektur sejumlah 90 orang sampel. Adapun sampel dari kelompok ini terbagi menjadi tiga kategori yaitu 30 orang berasal dari mahasiswa arsitektur semester enam ke atas, 30 orang dosen arsitektur, serta 30 orang praktisi arsitek. Pertimbangan pemilihan sampel pada kelompok ini adalah bahwa para paraktisi dan akademisi di bidang arsitektur mampu menilai kualitas visual fasade bangunan berdasarkan prinsip dan kaidah estetika.

Metode pemilihan stimuli adalah sebagai berikut:

- Masing-masing bangunan dipetakan sesuai dengan gaya bangunan.

- Dilakukan pengelompokan bangunan modern pasca kolonial.

- Dianalisis dan diseleksi satu bangunan yang representatif untuk mewakili kelompok gaya arsitektur modern pasca kolonial.

Metode analisis menggunakan analisis independent sample t-test untuk mengetahui perbandingan penilaian antar dua kelompok responden, serta analisis faktor, dan analisis regresi linier berganda untuk mengetahui elemen visual yang paling berpengaruh terhadap tampilan fasade bangunan modern. 


\section{Hasil Dan Pembahasan}

Bangunan A (Gambar 1) merupakan bangunan yang mewakili kelompok gaya arsitektur modern pasca kolonial.

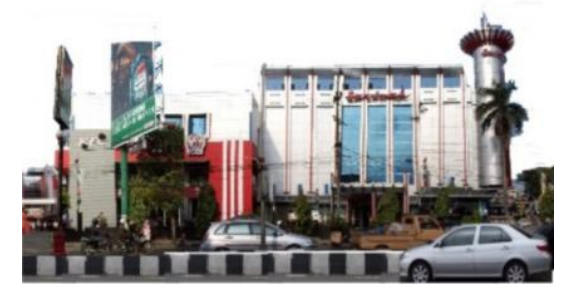

Gambar 1. Bangunan A

Berdasarkan analisis independent sample t-test, maka didapatkan hasil perbandingan penilaian antar responden sebagai berikut (Tabel 1):

Tabel 1. Penilaian Responden Pada Bangunan A

\begin{tabular}{|c|c|c|c|c|}
\hline \multirow[t]{2}{*}{ No. } & \multirow[t]{2}{*}{ Variabel } & \multicolumn{2}{|c|}{ Kelompok Responden } & \multirow{2}{*}{$\begin{array}{l}\text { Perbandingan } \\
\text { penilaian }\end{array}$} \\
\hline & & Masyarakat & Profesional & \\
\hline 1. & Gaya arsitektural & Penting & Agak penting & Berbeda \\
\hline 2. & Bentuk fasade & Penting & Agak penting & Sama \\
\hline \multirow[t]{3}{*}{3.} & Garis & & & \\
\hline & Horizontal & Agak penting & Agak penting & Sama \\
\hline & Vertikal & Agak penting & Agak penting & Sama \\
\hline \multirow[t]{9}{*}{4.} & Bidang & & & \\
\hline & Pintu: & & & \\
\hline & -Perulangan bentuk & Agak penting & Agak penting & Sama \\
\hline & -Bentuk & Agak penting & Agak penting & Sama \\
\hline & -Proporsi & Agak penting & Agak penting & Sama \\
\hline & Lendela: & & & \\
\hline & -Perulangan bentuk & Agak penting & Agak penting & Sama \\
\hline & -Bentuk & Agak penting & Agak penting & Sama \\
\hline & -Proporsi & Agak penting & Agak penting & Sama \\
\hline \multirow[t]{4}{*}{5.} & Warna: & & & \\
\hline & $\begin{array}{l}\text { Warna fasade } \\
\text { Jenis warna yang sesuai }\end{array}$ & $\begin{array}{l}\text { Penting } \\
\text { Warna netral }\end{array}$ & $\begin{array}{l}\text { Penting } \\
\text { Warna netral }\end{array}$ & Berbeda \\
\hline & Kemurnian warna & Agak penting & Agak penting & Sama \\
\hline & Kecerahan warna & Penting & Agak penting & Berbeda \\
\hline 6. & Tekstur & Agak penting & Agak penting & Berbeda \\
\hline 7. & Ornamen dekoratif & Penting & Agak penting & Berbeda \\
\hline 8. & Material & Penting & Agak penting & Berbeda \\
\hline 9. & Kualitas tampilan & Biasa & Agak indah & Berbeda \\
\hline
\end{tabular}

Berdasarkan data pada Tabel 1, sepuluh unsur visual memiliki kesamaan penilaian oleh dua kelompok responden, sedangkan enam unsur visual memiliki penilaian yang berbeda antar kelompok responden. Pada bangunan A, rata-rata penilaian antar kedua kelompok responden tidak terlalu besar perbedaannya, yaitu masing-masing berkisar di antara rentang skala penilaian "agak penting" dan "penting". Implikasi hasil analisis ini adalah untuk menentukan unsur visual yang 
dianggap penting menurut pendapat masyarakat maupun profesional. Masyarakat sebagai penikmat dan penghuni kota memiliki penilaian yang seharusnya diperhatikan dan dijadikan pertimbangan khusus bagi profesional dalam merancang wujud fisik kota. Ini dapat dijadikan referensi bahwa secara keseluruhan, penilaian antara masyarakat dan profesional hampir sama dan tidak jauh berbeda tentang peranan masing-masing unsur visual terhadap kualitas visual fasade bangunan modern. Bangunan A adalah bangunan yang mewakili kelompok bangunan bergaya arsitektural modern yang dibangun pasca kolonial. Masyarakat dan profesional memberikan penilaian yang sama terhadap peranan masing-masing unsur visual terhadap tampilan fasade bangunan $\mathrm{A}$, dengan memberikan perhatian terhadap keberadaan bangunan A dalam konteks kawasan dan lingkungan sekitarnya. Responden menilai peranan unsur visual pada bangunan A dengan mempertimbangkan kaitan antara keberadaan bangunan tersebut dengan pembentukan harmonisasi dan kontinuitas dengan bangunan lainnya di koridor jalan wilayah studi.

Berdasarkan hasil analisis pendahuluan, dapat diketahui bahwa seluruh variabel dapat disertakan ke dalam analisis faktor. Masing-masing variabel yang memiliki korelasi tinggi akan mengelompok ke dalam suatu faktor. Berdasarkan hasil analisis, terdapat tiga faktor yang terbentuk pada data bangunan A. Masingmasing faktor terdiri dari variabel-variabel dengan nilai loading factor $>0.5$ (Tabel 2). Faktor yang pertama terdiri dari enam variabel yaitu perulangan bentuk pintu, bentuk pintu, proporsi pintu, perulangan bentuk jendela, bentuk jendela, dan proporsi jendela. Masing-masing variabel merupakan unsur-unsur visual pembentuk bidang fasade, sehingga faktor pertama diberi nama Komponen Bidang. Faktor yang kedua terdiri dari empat variabel, yaitu gaya arsitektural, bentuk fasade, garis horisontal, dan garis vertikal. Keempat faktor tersebut merupakan unsur visual penyusun bentuk geometri fasade, sehingga faktor yang kedua diberi nama Komponen Geometri. Faktor yang ketiga terdiri dari enam variabel, yaitu tekstur, ornamen, material, warna muka bangunan, kemurnian warna, serta kecerahan warna. Variabel-variabel tersebut merupakan komponen pembentuk efek raba visual serta penyusun dimensi warna, sehingga faktor yang ketiga diberi nama Komponen Efek Raba Visual \& Dimensi Warna. 


\section{Tabel 2. Hasil Rotasi Faktor Pada Bangunan A}

\begin{tabular}{|c|c|c|c|}
\hline \multirow[t]{2}{*}{ Variable } & \multicolumn{3}{|c|}{ Component } \\
\hline & 1 & 2 & 3 \\
\hline Gaya arsitektural (Bentuk geometri) & .205 & .787 & .144 \\
\hline Bentuk fasade (Bentuk geometri) & .308 & .761 & .238 \\
\hline Garis horisontal (Bentuk geometri) & .195 & .756 & .199 \\
\hline Garis vertikal (Bentuk geometri) & .215 & .636 & .277 \\
\hline Perulangan bentuk pintu (Bidang) & .804 & .011 & .296 \\
\hline Bentuk pintu (Bidang) & .797 & .274 & .138 \\
\hline Proporsi pintu (Bidang) & .765 & .228 & .287 \\
\hline Perulangan bentuk jendela (Bidang) & .700 & .257 & .091 \\
\hline Bentuk jendela (Bidang) & .707 & .443 & -.023 \\
\hline Proporsi jendela (Bidang) & .696 & .294 & .293 \\
\hline Warna muka bangunan (Dimensi warna) & .286 & .313 & .653 \\
\hline Kemurnian warna (Dimensi warna) & .231 & .002 & .795 \\
\hline Kecerahan warna (Dimensi warna) & .115 & .321 & .741 \\
\hline Tekstur (Efek raba visual) & .199 & .328 & .693 \\
\hline Ornamen dekoratif (Efek raba visual) & .134 & .271 & .749 \\
\hline Material (Efek raba visual) & .239 & .472 & .540 \\
\hline
\end{tabular}

Extraction Method: Principal Component Analysis.

Rotation Method: Varimax with Kaiser Normalization.

a. Rotation converged in 6 iterations.

Setelah dilakukan analisis faktor, untuk mengetahui faktor manakah yang memberikan pengaruh signifikan terhadap penilaian responden terhadap bangunan A, digunakan analisis regresi berganda. Berdasarkan analisis uji F (uji simultan) dan uji t (uji parsial) pada data bangunan A, maka didapatkan model regresi yang menunjukkan adanya pengaruh signifikan beberapa komponen variabel terhadap kualitas visual fasade bangunan A (Tabel 3).

Tabel 3. Model Regresi Pada Kualitas Visual Fasade Bangunan A

\begin{tabular}{lllll}
\hline Variable & Coefficient & $\begin{array}{l}\text { Standardized } \\
\text { Coefficient }\end{array}$ & $\boldsymbol{t}$-statistic & $\boldsymbol{P}$-value \\
\hline Constant & 4.727 & & 46.203 & 0.000 \\
Komponen Bidang & 0.122 & 0.083 & 1.192 & 0.235 \\
Komponen Geometri & 0.457 & 0.310 & 4.464 & 0.000 \\
Komponen Efek Raba Visual \& Dimensi Warna & 0.332 & 0.225 & 3.243 & 0.001 \\
$R$-square & 0.154 & & & \\
Adjusted $R$-square & 0.140 & & & \\
\hline
\end{tabular}

a. Dependent Variable: Kualitas Visual Fasade

Berdasarkan hasil analisis regresi pada bangunan A, maka diperoleh persamaan regresi sebagai berikut:

$$
\begin{aligned}
& \mathrm{Y}=4.727+0,122 \mathrm{X} 1+0,457 \mathrm{X} 2+0,322 \mathrm{X} 3+\mathrm{e} \\
& \mathrm{Y}: \text { Kualitas visual fasade (Dependent variable) } \\
& \mathrm{X} 1: \text { Komponen Bidang } \\
& \mathrm{X} 2: \text { Komponen Geometri } \\
& \mathrm{X} 3: \text { Komponen Efek Raba Visual \& Dimensi Warna }
\end{aligned}
$$

Hasil uji parsial menunjukkan bahwa Komponen Geometri dan Komponen Efek Raba Visual \& Dimensi Warna memberikan pengaruh yang signifikan terhadap penilaian responden pada bangunan A, yaitu ditunjukkan oleh nilai signifikansi $\mathrm{t}$ $<0,05$. Merujuk pada nilai Standardized Coefficients Beta dari kedua faktor tersebut, 
maka Komponen Geometri memiliki nilai yang terbesar sehingga merupakan faktor yang paling berpengaruh terhadap penilaian kualitas visual fasade bangunan A. Faktor berikutnya yang paling berpengaruh adalah Komponen Efek Raba Visual \& Dimensi Warna.

Tabel 4 menunjukkan kelompok unsur visual yang paling berpengaruh terhadap tampilan fasade bangunan $\mathrm{A}$, sesuai urutan pentingnya peranan masingmasing kelompok.

\section{Tabel 4. Unsur Visual Yang Paling Berpengaruh Pada Bangunan A}

\begin{tabular}{cl}
\hline Kelompok & \multicolumn{1}{c}{ Jenis unsur visual } \\
\hline Komponen Geometri & Gaya arsitektural, bentuk fasade, garis horisontal, garis \\
vertikal, & Tekstur, ornament dekoratif, material, warna muka \\
bomponen Efek Raba Visual \& Dimensi & $\begin{array}{l}\text { barna } \\
\text { bangunan, kemurnian warna, kecerahan warna }\end{array}$ \\
\hline
\end{tabular}

Komponen Geometri merupakan komponen yang paling berpengaruh terhadap kualitas visual fasade bangunan A. Hal ini sesuai dengan hasil penelitian Smardon (1986) tentang peranan bentuk dan garis fasade dan Askari (2009) tentang peranan gaya arsitektur dan bentuk fasade untuk membentuk kualitas visual fasade, khususnya di kawasan bersejarah. Bangunan A merupakan bangunan modern yang dibangun setelah masa kolonial, sehingga sangat penting untuk memperhatikan Komponen Geometri yang membentuk fasade bangunan, dalam kaitan keselarasan dan harmonisasi dengan bangunan lain di koridor Jalan Kayutangan. Komponen berikutnya yang paling berpengaruh adalah Komponen Efek Raba Visual \& Dimensi Warna. Komponen ini sangat penting peranannya untuk membentuk kualitas visual fasade bangunan modern di wilayah studi, karena erat kaitannya dengan harmonisasi fasade bangunan modern dengan lingkungan sekitarnya yang berkarakteristik kolonial. Penggunaan material, ornamen dan pemilihan tekstur fasade akan menciptakan efek raba visual yang dapat menyatukan gaya arsitektur modern dengan bangunan kolonial lainnya. Terlebih lagi, pemilihan jenis warna fasade akan sangat menentukan kesinambungan keseluruhan tampilan fasade bangunan A yang modern dengan bangunan lainnya yang bergaya nieuwe bowen dan neo gothik. Menurut penilaian responden, jenis warna paling sesuai untuk bangunan A adalah warna netral, atas pertimbangan kesatuan (unity) dan harmoni dengan bangunan sekitarnya yang bergaya kolonial. Karenanya, komponen-komponen yang paling berpengaruh terhadap kualitas visual fasade banguan A, sangat erat kaitannya dengan pembentukan tampilan fasade bangunan dalam keberadaannya pada konteks kawasan bersejarah.

Berdasarkan hasil analisis regresi pada bangunan A, diperoleh nilai $R$ square sebesar 0,154. Ini menunjukkan hanya sebesar $15,4 \%$ varians variabel terikat (kualitas visual fasade bangunan A) yang mampu dijelaskan oleh seluruh variabel terikat. Sehingga masih terdapat $84,6 \%$ faktor lain yang tidak termasuk dalam penelitian ini yang mampu mempengaruhi kualitas visual fasade bangunan $\mathrm{A}$. Faktor lain tersebut diantaranya adalah unsur perseptual yang berhubungan dengan konteks keberadaan bangunan A dalam skala kawasan, yaitu keterkaitan visual dengan bangunan lainnya serta lingkungan meso maupun makro. 


\section{Kesimpulan}

Berdasarkan hasil analisis dan pembahasan, maka dapat ditarik beberapa kesimpulan sebagai hasil penelitian ini, sesuai dengan tujuan penelitian yang ingin dicapai, yaitu sebagai berikut:

1. Penilaian antara masyarakat dan kalangan profesional di bidang arsitektur (yang terdiri dari praktisi arsitek, dosen arsitektur dan mahasiswa arsitektur) mengenai peranan unsur visual dalam membentuk kualitas visual fasade bangunan modern pasca kolonial di Kayutangan yang baik dan indah, memiliki penilaian yang hampir sama pada masing-masing aspek visual yang dinilai. Perbedaan cara pandang penilaian, disebabkan oleh perbedaan pengetahuan, penguasaan teori maupun praktik perancangan, dan estetika. Implikasi hasil analisis ini adalah sebagai referensi bagi para arsitek, perencana kota maupun perencana lingkungan untuk memperhatikan komponen unsur visual fasade bangunan modern di Kayutangan, sesuai kesamaan visi dan penilaian masyarakat serta profesional mengenai pentingnya peranan unsur visual terhadap tampilan fasade bangunan modern yang indah di Jalan Kayutangan. Kedua kelompok responden memiliki penilaian yang tidak jauh berbeda terhadap peranan masingmasing unsur visual, yaitu dalam rentang skala penilaian "agak penting" sampai dengan "penting".

2. Komponen visual yang paling berpengaruh terhadap kualitas fasade bangunan modern pasca kolonial di Kayutangan yaitu Komponen Geometri (gaya arsitektural, bentuk fasade, garis horisontal, dan garis vertikal) dan Komponen Efek Raba Visual \& Dimensi Warna (tekstur, ornamen, material, warna muka bangunan, kemurnian warna, serta kecerahan warna). Hal ini dapat dicermati sebagai salah satu upaya untuk menciptakan estetika lingkungan di koridor Jalan Kayutangan, dengan memperhatikan aspekaspek visual bangunan modern sesuai konteks lingkungan dan kawasan.

\section{Daftar Pustaka}

Askari, Hossein Amir \& Dola, Kamariah Binti. (2009). Influence of Building Facade Visual Elements on Its Historical Image: Case of Kuala Lumpur City, Malaysia. Journal of Design and Built Environment. Vol. 5: 49-59.

Masri, Andry. (2010). Strategi Visual. Yogyakarta: Jalasutra.

Portella, Adriana Araujo (2007). Evaluating Commercial Signs In Historic Streetcapes: The Effects of the Control of Advertising and Signage on User's Sense of Environmental Quality.. PhD Thesis. England: Oxford Brookes University.

Rizaldi, Tito L.N., Hariyani, S., \& Wardhani, D.K. (2010). Pelestarian Lingkungan dan Bangunan Kuno Bersejarah Kawasan Kayutangan Kota Malang. arsitektur ejournal. 3(2): 120-136.

Smardon, Richard. (1986). Foundation for Visual Project Analysis. New York: John Wiley \& Sons. 